\title{
Bioprospecting brown algae (Sargassum polycystum C. Agardh) as a potential antioxidant additive in snack bar and its sensory evaluation
}

\author{
1, ${ }^{*}$ Nurcahyanti, A.D.R., ${ }^{2}$ Puika, V.I., ${ }^{2}$ Pramitasari, R. and ${ }^{1}$ Notario, D. \\ ${ }^{1}$ Department of Pharmacy, School of Medicine and Health Sciences, Atma Jaya Catholic University of \\ Indonesia, Pluit Raya 2, 14440 Jakarta, Indonesia \\ ${ }^{2}$ Department of Food Technology, Faculty of Biotechnology, Atma Jaya Catholic University of Indonesia, \\ Raya Cisauk Lapan, Sampora, 15345 Banten, Indonesia
}

\section{Article history:}

Received: 14 April 2021

Received in revised form: 25

May 2021

Accepted: 31 July 2021

Available Online: 21

November 2021

Keywords:

Sargassum polycystum,

Fucoxanthin,

Antioxidant,

Snack bar

DOI:

https://doi.org/10.26656/fr.2017.5(6).266

\begin{abstract}
Fucoxanthin from brown algae has potential as a promising functional food component. However, fucoxanthin is less stable under high temperature and light exposure. The purpose of this study was to analyse the effect of stevia and cacao butter in increasing the stability of Sargassum polycystum C. Agardh extract containing fucoxanthin and its application as a snack bar. Brown algae, S. polycystum, was extracted using $96 \%$ foodgrade ethanol. Antioxidant activity and stability assay were performed using the 2,2Diphenyl-1-Picrylhydrazyl (DPPH) method. Antioxidant activity of both, extract (E) and extract + stevia (ES), was found to decrease with time. Meanwhile, cacao butter was able to maintain extract's stability without any significant difference when compared to extract alone. A combination of extract, stevia, and cacao butter (ESC) were found to be able to maintain antioxidant stability. Formulation of a snack bar with cacao butter and $1 \%$ stevia were more preferred by the panellists when compared to the other formulations. This study reports that cacao butter and $1 \%$ stevia is able to maintain antioxidant stability and improve the economic value of $S$. polycystum, one of them through the formulations of the snack bar.
\end{abstract}

\section{Introduction}

Bioprospecting for sustainable antioxidant sources is promising opportunity since nature provides an abundant source of bioactive compounds. Utilization of the terrestrial resources has become the attention of major pharmaceutical and food industries worldwide (Dias et al., 2012). Limited application of marine resources is unfortunate as invertebrates, microalgae, and macroalgae that are usually found in these areas produce unique chemical substances with different biological activities (Montaser and Luesch, 2011; Martins et al., 2014). Macroalgae, such as Sargassum, has been used for ages in Traditional Chinese Medicine as seaweed medicine (Liu et al., 2012). Macroalgae are highly distributed and can be found in abundance. They can be easily harvested and huge potential lies in exploring and developing them as a commercial product. It is the potential to explore and develop as commercial product, especially for coastal communities (Loureiro et al., 2015; Kim et al., 2017).

Macroalgae or seaweed is categorized - based on their pigmentation properties - as brown algae (Phaeophyceae), red algae (Rhodophyceae), and green seaweed (Chlorophyceae) (Biris-Dorhoi et al., 2020). Brown algae have gained scientific interest due to carotenoids and phenolics contained that are beneficial for human health (Catarino et al., 2017; Hakim and Patel, 2020; Miyashita et al., 2020). The concentration of bioactive substances has been found to vary with geography and seasons, affecting not only metabolites production but also their biological activity (Wells et al., 2017). Examples of other algae that contains fucoxanthin are Alaria esculenta blade $(0.87 \mathrm{mg} / \mathrm{g})$ dry mass, Fucus vesiculosus $(0.69 \mathrm{mg} / \mathrm{g})$ and Laminaria digitata $(0.65$ $\mathrm{mg} / \mathrm{g}$ ) (Shannon and Abu-Ghannam, 2017).

Fucoxanthin is a major pigment present in brown algae (Xiao et al., 2012) and it has been well reported to possess a broad spectrum of pharmacological properties including antioxidant, anti-inflammatory, neuroprotector, and antiobesity activity (Peng et al., 2011; Gammone and D'Orazio, 2015; Mohibbullah et al., 2018). Carotenoids and phenolics in macroalgae have been proven to be associated with antioxidant activity, with 
fucoxanthin being the lead compound responsible for this (Foo et al., 2017). Fucoxanthin harbours alenic and 5,6-monoepoxide bonds (Miyashita et al., 2011; Shang et al., 2011) that is responsible for various pharmacological effects, including anti-oxidant (Yu et al., 2018) which is achieved by scavenging free radicals (Foo et al., 2017; Mohibbullah et al., 2018).

The aim of this study was the development of a snack bar enriched with brown algae extract from Sargassum polycystum C. Argardh, as a functional food. The different formulations used in this study were chosen while the low stability of fucoxanthin under acidic $\mathrm{pH}$, temperature, and bright light led to its degradation (Zhao et al., 2019). A snack bar can be produced under a simple process and formulated in lowtemperature settings. Due to the low stability of algal bioactive substances, such as fucoxanthin, cacao butter was tested as a stabilizing agent. Cacao butter is unique as it is brittle and melts quickly at room temperature. It also contains less polar bioactive substances - similar to fucoxanthin (a less polar carotenoid). Cacao butter contains triglycerides (triacylglycerols) as the main components along with other oils and fats. Triglycerides are esters of glycerol and fatty acids in which carbon atoms numbered 1-3 of glycerol are most often interchangeable and very difficult to differentiate, and the 2-position is of special interest. This position of fatty acid is responsible for nutritional and functional values (Lipp and Anklam, 1998). Another important ingredient used in this study was stevia (Ahmad and Ahmad, 2018). The effect of cacao butter and stevia to retain antioxidant activity was assessed and sensory evaluation in snack bar formulation was discussed.

\section{Materials and methods}

\subsection{Materials}

Sargassum polycystum was collected from Sumbawa district, West Nusa Tenggara between April and May 2019. Morphological identification was performed by a senior marine biologist at the Research Center for Oceanography, Indonesian Institute of Sciences. 2,2Diphenyl-1-Picrylhydrazyl (DPPH), methanol, DMSO, and fucoxanthin standard were purchased from SigmaAldrich USA. Ethanol and distilled water were obtained as an analytical grade. Cacao butter, stevia powder, and other snack bar ingredients like creamer, dried coconut, rolled oats, crispy rice, raisins, and almonds were purchased from a supermarket in South Jakarta.

\subsection{Preparation of Sargassum polycystum and extraction}

Sargassum polycystum was washed and air-dried for 5 days. Sargassum polycystum was then dried at $45^{\circ} \mathrm{C}$ for $8 \mathrm{hrs}$. Dried $S$. polycystum was pulverized using a food processor and filtered using a 40 mesh sieve. Sargassum polycystum powder was placed in a dark and well-sealed container at $25^{\circ} \mathrm{C}$. Sargassum polycycstum is extracted following methods developed by Delbrut et al. (2018) with slight modification on duration (Delbrut et al., 2018). The extract was macerated in Ethanol absolute at 1:5 ratio and placed at $100 \mathrm{rpm}$ orbital shaker. After $24 \mathrm{hrs}$, the solvent was evaporated using a vacuum rotary evaporator at $40^{\circ} \mathrm{C}, 60 \mathrm{rpm}$. The remaining solvent was evaporated by blowing using liquid nitrogen. The solvent-free extract was sealed and placed at $4{ }^{\circ} \mathrm{C}$ and in dark until further analysis.

\subsection{High-performance liquid chromatography-PDA}

Analysis of fucoxanthin content was performed using High-Performance Liquid Chromatography (HPLC) Prominence Shimadzu and diode array SPDM20A. Solid-phase used was C30 YMC $(150 \mathrm{~mm} \times 4.6$ $\mathrm{mm}$; Particle Size $5 \mu \mathrm{m}$ ), whereas the mobile phases used were methanol, methyl tert-butyl ether (MTBE), and distilled water HPLC grade (85:11:4). The flow rate was maintained at $1 \mathrm{~mL} /$ minute isocratic. The sample was filtered using $0.20 \mu \mathrm{m}$ Minisart filters, then $20 \mu \mathrm{L}$ was injected into the loop-injector. Detection of fucoxanthin was performed using a photodiode array $(190-800 \mathrm{~nm})$ at $446 \mathrm{~nm}$. Fucoxanthin (Sigma Aldrich) was used to make a standard curve.

\subsection{Antioxidant assay}

Antioxidant activity of all ingredients was measured using the DPPH method as developed in a previous study by Brand-Williams et al. (1995). In brief, the sample was diluted in ethanol absolute and diluted in the same solvent for the assay. Serial dilution of the sample or extract standard was mixed with $1 \mathrm{~mL}$ DPPH $0.05 \mathrm{mM}$ in Ethanol 96\%. The mixture was incubated for 30 mins away from direct light exposure and the absorbance $\left(\mathrm{A}_{1}\right)$ was measured at $517 \mathrm{~nm}$. Ethanol was used as the blank and measured at the same wavelength $\left(\mathrm{A}_{0}\right)$. Scavenging ability (\%) was calculated by using the formula:

$$
\text { Scavenging ability }(\%)=\left[\frac{(\mathbf{A 0}-\mathbf{A 1})}{\mathrm{A0}}\right] \times 100
$$

where $\mathrm{A}_{0}$ was the absorbance of reaction control and $A_{1}$ was the absorbance of the sample

\subsection{Effect of cacao butter, stevia, and its combination on antioxidant activity}

Different formulations containing different amounts of $S$. polycystum extract, cacao butter, and stevia are described in Table 1. The combination was examined for their antioxidant activity using the DPPH method as described above at day- 0,1 , and 6 . Formulation and measurement of antioxidant activity were performed at room temperature $\left(25^{\circ} \mathrm{C}\right)$ and low light exposure. 
Table 1. Different combination of $S$. polycystum extract, cacao butter, and stevia

\begin{tabular}{|c|c|c|c|c|}
\hline Ingredient & 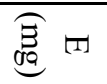 & 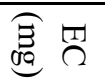 & 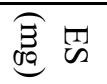 & 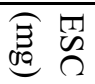 \\
\hline S. polycystum extract & 10 & 10 & 10 & 10 \\
\hline Cacao butter & 0 & 100 & 0 & 100 \\
\hline Stevia & 0 & 0 & 100 & 100 \\
\hline
\end{tabular}

$\mathrm{E}=S$. polycystum extract, $\mathrm{EC}=S$. polycystum extract + cacao butter, $\mathrm{ES}=S$. polycystum extract + stevia, $\mathrm{ESC}=S$. polycystum extract + stevia + cacao butter

\subsection{Snack bar formulation enriched with Sargassum polycystum extract}

The snack bar was sized at $30 \mathrm{~g}$ apiece (Table 2). Tempering of cacao butter was performed using the double boiler method until the temperature reached $35^{\circ}$ C. Sargassum polycystum extract was then added, followed by creamer and stevia. The mixture was stirred until it cooled down to $25^{\circ} \mathrm{C}$. The mixture was maintained at $25^{\circ} \mathrm{C}$ for 10 mins. The remaining ingredients were then added, mixed thoroughly, and allowed to sit until they solidified. The snack bar was stored at $25^{\circ} \mathrm{C}$, in a well-sealed food container and kept away from direct light.

Table 2. Formulation of snack bar

\begin{tabular}{lccc}
\hline \multirow{2}{*}{ Ingredient } & \multicolumn{3}{c}{ Formula $(\mathrm{g})$} \\
\cline { 2 - 4 } & 1 & 2 & 3 \\
\hline Cacao butter & 9.945 & 9.895 & 9.745 \\
Stevia & 0.05 & 0.1 & 0.25 \\
S. polycystum extract & 0.005 & 0.005 & 0.005 \\
Creamer powder & 5 & 5 & 5 \\
Dried coconut & 3 & 3 & 3 \\
Rolled oats & 3 & 3 & 3 \\
Crispy rice & 3 & 3 & 3 \\
Raisin & 3 & 3 & 3 \\
Almond & 3 & 3 & 3 \\
\hline
\end{tabular}

\subsection{Texture analysis of snack bar}

Texture analysis was performed using a texturometer (Agrosta, France). Individual snack bar formulas were tested in triplicates following methods developed by (Arozarena et al., 2012). Hardness level was the parameter observed for this analysis and a commercial product (Fitbar Fruits, Kalbe) served as the control.

\subsection{Sensory evaluation of snack bar}

Sensory evaluation was performed using the hedonic assay (Meilgaard MC, Civille GV, 2016). The panellists consisted of 30 semi-trained individuals and the parameters tested were colour, appearance, aroma, texture, taste, aftertaste, and overall appearance. Each parameter was scored on a scale ranging from 1 (least favoured) to 9 (most favoured). Formulation with the highest score was used in further analysis.

\subsection{Proximate analysis}

Proximate analysis was performed to identify the presence of carbohydrates, protein, lipid, and fibre including micronutrients such as vitamin A, vitamin $\mathrm{C}$, and vitamin $\mathrm{E}$ and carried out based on the International Standard guideline and the Weende proximate analysis system (Badan Standardisasi Nasional (BSN), 2008). Analysis was performed in the Laboratory of the Indonesian Ministry of Agriculture.

\subsection{Shelf-life analysis}

Shelf-life analysis of snack bar with formula 2 was performed for 28 days at 7-day intervals. Moisture or water content using the standard gravimetric method (Vera Zambrano et al., 2019), microbial contamination using the standard total plate count (TPC) method (Udayasoorian et al., 2017), and water activity using Aqua lab 4TE were measured during this period. All analysis was performed in triplicates.

\subsection{Statistic analysis}

Data from an organoleptic test, texture analysis, and self-life analysis was analyzed using one-way ANOVA followed by Duncan analysis to identify the presence of significant differences in treatment at a $95 \%$ confidence interval. Analysis of Dose-Response Curves was used in the antioxidant analysis.

\section{Results and discussion}

\subsection{Extraction, identification, and antioxidant activity of fucoxanthin}

The extraction yielded $0.70 \%$ of crude extract, slightly higher than what Gazali et al. (2018) reported, 0.56\% (Gazali et al., 2018). Fucoxanthin peak was detected at a retention time of 3.954 minutes similar to the retention time of standard. The concentration of fucoxanthin obtained in this study, measured with HPLC, was $1.79 \mathrm{mg} / \mathrm{g}$ extract. Vieira et al. (2017) suggested fucoxanthin concentration in the carotenoid extract is in the range of 0.1 to $1.89 \mathrm{mg} / \mathrm{g}$ Sargassum $\mathrm{sp}$ dry mass (Martins et al., 2014).

Antioxidant activity of $S$. polycystum extract and individual ingredients was in descending order were as follows: ascorbic acid (positive control) $>$ rice crispy $>$ $S$. polycystum extract $>$ cacao butter $>$ raisin $>$ stevia powder $>$ almond $>$ dried coconut $>$ rolled oats $>$ creamer powder (Table 3).

On its own, $S$. polycystum extract has an $\mathrm{IC}_{50}$ value of $0.16 \pm 0.03 \mathrm{mg} / \mathrm{mL}$. A study on the algal, antioxidant activity showed that carotenoids and phenolics are significantly associated with antioxidant activity. 
Fucoxanthin is one of the dominant substances responsible for the activity (Foo et al., 2017). In addition, the activity can be due to the synergistic effect between fucoxanthin and phenolics contained in the extract, one of them by preventing oxidative reaction and scavenging superoxide anions $\left(\mathrm{O}^{\circ}{ }^{\circ}\right)$ (Miyashita et al., 2011; Peng et al., 2011). Crispy rice showed profound antioxidant activity compared to other ingredients. This could be due to the presence of added antioxidant agents such as vitamin E and butylated hydroxytoluene (BHT) to maintain the stability and shelf-life of a food product. In addition, processing technology to produce crispy rice may also affect the active compounds in rice such as catechin and cyanidin 3-O-glucoside with potential antioxidant activity. A rice cooker and water bath are the best techniques to maintain losses of phenolics in rice. Other than that methods, processing rice can diminish active substances, such as boiling and removing the remaining cooking water, microwave, and pressure cooker (Fracassetti et al., 2020). Cacao butter contains fatty acids like oleic acid, palmitic acid, and stearic acid that are able to scavenge free radicals (Torres-Moreno et al., 2015). In addition, high phenolics content in cacao is also responsible for its antioxidant activity(Maleyki and Ismail, 2010; Katz et al., 2011). Other ingredients showed some degree of antioxidant activity, this may be due to the processing technologies causing partial or full degradation of bioactive substances (Al-juhaimi et al., 2018)

Table 3. $\mathrm{IC}_{50} \mathrm{DPPH}$ of snack bar ingredients

\begin{tabular}{lc}
\hline Ingredient & $\mathrm{IC}_{50}(\mathrm{mg} / \mathrm{mL})$ \\
\hline Ascorbic acid & $0.0018 \pm 0.00$ \\
Crispy rice & $0.11 \pm 0.03$ \\
S. polycystum & $0.16 \pm 0.03$ \\
Cacao butter & $0.37 \pm 0.03$ \\
Raisin & $1.84 \pm 0.08$ \\
Stevia powder & $2.37 \pm 0.08$ \\
Almond & $3.85 \pm 1.30$ \\
Dried coconut & $11.78 \pm 0.91$ \\
Rolled oats & $21.90 \pm 0.64$ \\
Powder creamer & $46.92 \pm 0.21$ \\
\hline
\end{tabular}

3.2 Antioxidant activity combination of Sargassum polycystum extract, cacao butter, and stevia

Antioxidant activity of $S$. polycystum extract combined with cacao butter, stevia, or both of them was assessed and observed at day-0, 1, and 6 (Table 4). $S$. polycystum extract in combination with cacao butter showed greater antioxidant activity compared to its activity. This activity was maintained up until day-6. Synergistic effects can be explained due to the high content of fatty acids with low polarity improves the dissolution of the extract and thus improving the ability of active substances to scavenge free radicals. On the other hand, when the extract was combined with stevia, no improvement in antioxidant activity was observed (Table 4). The combination of three substances, extract, cacao butter, and stevia improved antioxidant activity when compared to the individual ingredients, however, a significant decrease is observed until day- $6(p<0.05$, Table 4).

In this study, antioxidant activity acts as one of the stability parameters. Compounds with antioxidant activity in $S$. polycystum synergistically interact with polyphenols, phenolics, phytosterols, and $\alpha$-tocopherol contained in cacao butter (Roiaini et al., 2016). Rao et al. (2007) observed that coconut oil, peanut oil, and mustard oil are able to maintain the stability of carotenoid astaxanthin esters due to the presence of polyphenols and $\alpha$-tocopherol in the oils (Rao et al., 2007). In addition, cacao butter consists of triglycerides possessing carbon atoms numbered -3 of glycerol that is most often interchangeable. This property protects $S$. polycystum extract and its bioactive compounds from oxidative reaction (Boon et al., 2010; Ergönül et al., 2010). Analysis of stability using analytical approaches such as chromatography is required for further analysis.

\subsection{Snack bar formulation enriched with Sargassum polycystum extract and texture analysis}

Figure 1 shows snack bar formulation enriched with $5 \mathrm{mg}$ S. polycystum extract. No visual difference is observed across the three formulations.

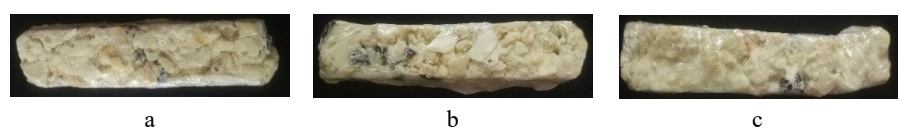

Figure 1. Snack bar formulation enriched with S. polycystum extract

Texture analysis was performed using a texturometer showing no significant difference was found among the three formulas when compared to a commercial snack

Table 4. Antioxidant activity of $S$. polycystum extract, cacao butter, stevia, and their combination

\begin{tabular}{ccccc}
\hline Day & S. polycystum extract & $\begin{array}{c}\text { S. polycystum extract }+ \\
\text { Stevia }\end{array}$ & $\begin{array}{c}\text { S. polycystum extract }+ \\
\text { Cacao butter }\end{array}$ & $\begin{array}{c}\text { S. polycystum extract }+ \\
\text { Cacao butter }+ \text { Stevia }\end{array}$ \\
\hline 0 & $2 . .65 \pm 0.66^{\mathrm{a}}$ & $6.96 \pm 0.32^{\mathrm{a}}$ & $1.54 \pm 0.17^{\mathrm{a}}$ & $1.72 \pm 0.08^{\mathrm{a}}$ \\
1 & $5.67 \pm 0.79^{\mathrm{b}}$ & $3.05 \pm 1.40^{\mathrm{b}}$ & $1.21 \pm 0.07^{\mathrm{b}}$ & $2.05 \pm 0.08^{\mathrm{b}}$ \\
6 & $12.62 \pm 0.89^{\mathrm{c}}$ & $9.23 \pm 0.23^{\mathrm{c}}$ & $1.56 \pm 0.05^{\mathrm{a}}$ & $3.02 \pm 0.17^{\mathrm{c}}$ \\
\hline
\end{tabular}

Values are presented as mean \pm SD. Values with different superscripts within the same row are significantly different at $95 \%$ confidence. 
$\operatorname{bar}(\mathrm{p} \geq 0.05$, Figure 2$)$.

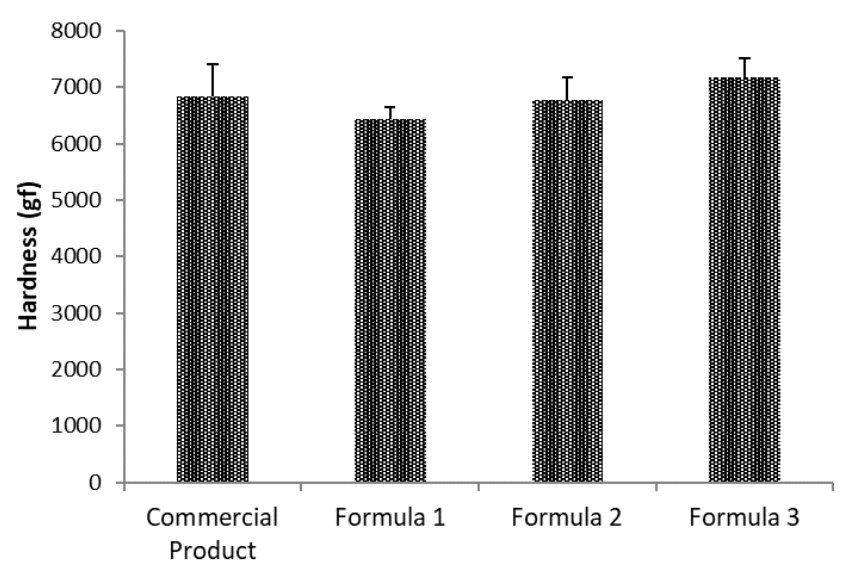

Figure 2. Texture of three snack bar formulas enriched with $S$. polycystum extract

\subsection{Organoleptic evaluation of snack bar}

Organoleptic evaluation is summarized in Table 5. Results obtained show that formula 2 is most favoured amongst the panellists. Based on the organoleptic evaluation, no significant difference was found in the colour, appearance, aroma, and texture of the three formulations, there were no significant differences among the three formulas. Based on taste and aftertaste, formula 3 was least favoured. Formula 3 contained the highest concentration of stevia that may have contributed to the bitter taste. Stevioside contained in stevia is responsible for the bitter taste and aftertaste. Other compounds such as volatile aromatics, tannins, and flavonoids may have also contributed to the bitter taste (Abou-arab et al., 2010). Formula 2 was chosen as the best formula from the organoleptic evaluation.

Table 5. Organoleptic analysis of three snack bar formulas

\begin{tabular}{llll}
\hline Criteria & Formula 1 & Formula 2 & Formula 3 \\
\hline Colour & $7.27 \pm 0.72^{\mathrm{a}}$ & $7.33 \pm 0.74^{\mathrm{a}}$ & $7.17 \pm 0.76^{\mathrm{a}}$ \\
Appearance & $6.93 \pm 1.47^{\mathrm{a}}$ & $6.90 \pm 1.28^{\mathrm{a}}$ & $6.90 \pm 1.22^{\mathrm{a}}$ \\
Aroma & $6.40 \pm 1.47^{\mathrm{a}}$ & $6.60 \pm 1.36^{\mathrm{a}}$ & $6.33 \pm 1.41^{\mathrm{a}}$ \\
Texture & $6.67 \pm 1.55^{\mathrm{a}}$ & $7.00 \pm 1.43^{\mathrm{a}}$ & $6.70 \pm 1.48^{\mathrm{a}}$ \\
Taste & $5.43 \pm 1.96^{\mathrm{a}}$ & $6.27 \pm 1.67^{\mathrm{a}}$ & $3.60 \pm 1.63^{\mathrm{b}}$ \\
Aftertaste & $5.17 \pm 2.12^{\mathrm{a}}$ & $5.83 \pm 1.64^{\mathrm{a}}$ & $3.60 \pm 1.69^{\mathrm{b}}$ \\
Overall & $5.67 \pm 1.69^{\mathrm{a}}$ & $6.50 \pm 1.31^{\mathrm{b}}$ & $4.53 \pm 1.57^{\mathrm{c}}$ \\
\hline
\end{tabular}

Values are presented as mean \pm SD. Values with different superscripts within the same column are significantly different at $95 \%$ confidence.

\subsection{Proximate analysis of snack bar}

Proximate analysis of the best snack bar formulation, formula 2, is described in Table 6 . The energy value of the $30 \mathrm{~g}$ snack bar was $144.33 \mathrm{kcal}$. A commercial snack bar used as a control in this study has an energy value of $132 \mathrm{kcal} / 30 \mathrm{~g}$. A snack bar with formula 2 is categorized as an intermediate energy snack bar as the total energy value lies in between energy snack bar $(280 \mathrm{kcal})$ and common snack bar (100 kcal) (Silva et al., 2013).

Table 6. Proximate analysis of formula 2

\begin{tabular}{lc}
\hline Component & Content (\%) \\
\hline Water content & 5.83 \\
Protein & 6.22 \\
Lipid & 45.55 \\
Fibre & 5.48 \\
Ash & 1.28 \\
Carbohydrate ready to use (available) & 35.64 \\
Total Carbohydrate & 41.12 \\
\hline
\end{tabular}

3.6 Snack bar shelf-life based on water content and water activity

There was no significant difference between water content on day- 0 to day-28 ( $\mathrm{p} \geq 0.05$, Table 7$)$. In addition, the water activity of snack bar formula 2 showed significant differences between day-0, 14, and $21(\mathrm{p}<0.05$, Table 7), and no significant difference between day-21 and day-28 ( $\mathrm{p} \geq 0.05$, Table 7). Total plate count (TPC) evaluation showed no microbial growth from day- 0 to day-28, indicating that snack bar formula 2 is safe for at least 28 days.

Table 7. Water content and water activity of formula 2 snack bar

\begin{tabular}{ccc}
\hline Day & Water Content & Water Activity $\left(\mathrm{A}_{\mathrm{w}}\right)$ \\
\hline 0 & $5.28 \pm 1.01^{\mathrm{a}}$ & $0.49 \pm 0.00^{\mathrm{a}}$ \\
7 & $5.43 \pm 0.93^{\mathrm{a}}$ & $0.54 \pm 0.00^{\mathrm{b}}$ \\
14 & $5.49 \pm 2.12^{\mathrm{a}}$ & $0.52 \pm 0.00^{\mathrm{c}}$ \\
28 & $6.09 \pm 1.03^{\mathrm{a}}$ & $0.50 \pm 0.00^{\mathrm{c}}$
\end{tabular}

Values are presented as mean \pm SD. Values with different superscripts within the same column are significantly different at $95 \%$ confidence.

Water activity $\left(\mathrm{A}_{\mathrm{w}}\right)$ is one of the factors affecting the growth of microbes in food. Microorganisms can grow only when water activity is greater than 0.61 (Rao et al., 2012). $A_{w}$ of formula 2 was between 0.49 and 0.54 showing that the snack bar possessed low water activity and thus no microbial growth was observed.

\section{Conclusion}

Sargassum polycystum extract contains fucoxanthin and showed high antioxidant activity. In combination with cacao butter, antioxidant activity can be maintained, whilst in combination with stevia, the antioxidant activity was reduced. When applied onto a snack bar formula, concentration of stevia $1 \%$ and cacao butter was able to maintain antioxidant activity and was the most favoured formula based on organoleptic evaluation by semi-trained panellists. This study reported the application of $S$. polycystum extract in combination with cacao butter as a promising functional food with 
enhanced antioxidant activity. This application is simple enough to be performed by local communities in coastal areas. A further investigation employing broader organoleptic evaluation and lower temperature processing is warranted to improve the quality and shelf life of the product.

\section{Conflict of interest}

The authors declare no conflict of interest.

\section{Acknowledgements}

The authors acknowledged field volunteers, Heni Sasmita, and the team for collecting the algae and apt. Erlia A Sianipar, M.Biomed. for helping in the identification of the algae. The research was funded by the Atma Jaya Catholic University of Indonesia on Project: Developing Healthy Snack bar from Brown Algae.

\section{References}

Abou-Arab, E., Abou-Arab, A. and Abu-salem, M.F. (2010). Physico-chemical assessment of natural sweeteners steviosides produced from Stevia rebaudiana bertoni plant. African Journal of Food Science, 4(5), 269-281.

Ahmad, U. and Ahmad, R.S. (2018). Anti-diabetic property of aqueous extract of Stevia rebaudiana Bertoni leaves in Streptozotocin-induced diabetes in albino rats. BMC Complementary and Alternative Medicine, 18(1), 179. https://doi.org/10.1186/s12906 $-018-2245-2$

Al-juhaimi, F., Ghafoor, K., Özcan, M.M., Jahurul, M.H.A., Babiker, E.E., Jinap, S., Sahena, F., Sharifudin, M.S. and Zaidul, I.S.M. (2018). Effect of various food processing and handling methods on preservation of natural antioxidants in fruits and vegetables. Journal of Food Science and Technology, 55(10), 3872-3880. https:// doi.org/10.1007/s13197-018-3370-0

Arozarena, I., Iguaz, A., Noriega, M., Bobo, G. and Vírseda, P. (2012). Physical properties of cereal products: measurement techniques and applications. In Arana, I. (Ed.), Physical Properties of Foods, $1^{\text {st }}$ ed. USA: CRC Press.

Badan Standardisasi Nasional (BSN). (2008). Perpustakaan Kementerian Perindustrian. Retrieved from Kementerian Perindustrian Republik Indonesia website: http://lib.kemenperin.go.id/neo/detail.php? id $=222773$

Biris-Dorhoi, E.-S., Michiu, D., Pop, C.R., Rotar, A.M., Tofana, M., Pop, O.L., Socaci, S.A. and Farcas, A.C.
(2020). Macroalgae - A Sustainable Source of Chemical Compounds with Biological Activities. Nutrients, 12(10), 3085. https://doi.org/10.3390/ nu12103085

Boon, C.S., McClements, D.J., Weiss, J. and Decker, E.A. (2010). Factors influencing the chemical stability of carotenoids in foods. Critical Reviews in Food Science and Nutrition, 50(6), 515-532. https:// doi.org/10.1080/10408390802565889

Brand-Williams, W., Cuvelier, M.E. and Berset, C. (1995). Use of a free radical method to evaluate antioxidant activity. LWT - Food Science and Technology, 28(1), 25-30. https://doi.org/10.1016/ S0023-6438(95)80008-5

Catarino, M.D., Silva, A.M.S. and Cardoso, S.M. (2017). Fucaceae: A source of bioactive phlorotannins. International Journal of Molecular Sciences, 18(6), 1327. https://doi.org/10.3390/ijms18061327

Delbrut, A., Albina, P., Lapierre, T., Pradelles, R. and Dubreucq, E. (2018). Fucoxanthin and polyunsaturated fatty acids co-extraction by a green process. Molecules, 23(4), $874 . \quad$ https:// doi.org/10.3390/molecules23040874

Dias, D.A., Urban, S. and Roessner, U. (2012). A Historical overview of natural products in drug discovery. Metabolites, 2(2), 303-336. https:// doi.org/10.3390/metabo2020303

Foo, S.C., Yusoff, F.M., Ismail, M., Basri, M., Yau, S.K., Khong, N.M.H., Chan, K.W. and Ebrahimi, M. (2017). Antioxidant capacities of fucoxanthinproducing algae as influenced by their carotenoid and phenolic contents. Journal of Biotechnology, 241, 175-183. https://doi.org/10.1016/ j.jbiotec.2016.11.026

Fracassetti, D., Pozzoli, C., Vitalini, S., Tirelli, A. and Iriti, M. (2020). Impact of cooking on bioactive compounds and antioxidant activity of pigmented rice cultivars. Foods, 9(8), 967. https:// doi.org/10.3390/foods 9080967

Gammone, M.A. and D’Orazio, N. (2015). Anti-obesity activity of the marine carotenoid fucoxanthin. Marine Drugs, 13(4), 2196-2214. https:// doi.org/10.3390/md13042196

Gazali, M., Nurjanah, N. and Zamani, N.P. (2018). Eksplorasi senyawa bioaktif alga cokelat Sargassum sp. Agardh sebagai antioksidan dari pesisir Barat Aceh. Jurnal Pengolahan Hasil Perikanan Indonesia, 21(1), 167-178. https://doi.org/10.17844/ jphpi.v21i1.21543 [In Bahasa Indonesia].

Hakim, M.M. and Patel, I.C. (2020). A review on phytoconstituents of marine brown algae. Future Journal of Pharmaceutical Sciences, 6, 129. https:// 
doi.org/10.1186/s43094-020-00147-6

Katz, D.L., Doughty, K. and Ali, A. (2011). Cocoa and chocolate in human health and disease. Antioxidants and Redox Signaling, 15(10), 2779-2811. https:// doi.org/10.1089/ars.2010.3697

Kim, J.K., Yarish, C., Hwang, E.K., Park, M. and Kim, Y. (2017). Seaweed aquaculture: Cultivation technologies, challenges and its ecosystem services. Algae, 32(1), 1-13. https://doi.org/10.4490/ algae.2017.32.3.3

Lipp, M. and Anklam, E. (1998). Review of cocoa butter and alternative fats for use in chocolate-Part A. Compositional data. Food Chemistry, 62(1), 73-97. https://doi.org/10.1016/S0308-8146(97)00160-X

Liu, L., Heinrich, M., Myers, S. and Dworjanyn, S.A. (2012). Towards a better understanding of medicinal uses of the brown seaweed Sargassum in Traditional Chinese Medicine: A phytochemical and pharmacological review. Journal of Ethnopharmacology, 142(3), 591-619. https:// doi.org/10.1016/j.jep.2012.05.046

Loureiro, R., Gachon, C.M.M. and Rebours, C. (2015). Seaweed cultivation: potential and challenges of crop domestication at an unprecedented pace. New Phytologist, 206(2), 489-492. https:// doi.org/10.1111/nph.13278

Maleyki, M. and Ismail, A. (2010). Antioxidant properties of cocoa powder. Journal of Food Biochemistry, 34(1), 111-128. https:// doi.org/10.1111/j.1745-4514.2009.00268.x

Martins, A., Vieira, H., Gaspar, H. and Santos, S. (2014). Marketed marine natural products in the pharmaceutical and cosmeceutical industries: Tips for success. Marine Drugs, 12(2), 1066-1101. https://doi.org/10.3390/md12021066

Meilgaard, M.C., Carr, V.T. and Civille, G.V. (2016). Sensory evaluation techniques. 5th ed. USA: CRC Press.

Miyashita, K., Beppu, F., Hosokawa, M., Liu, X. and Wang, S. (2020). Nutraceutical characteristics of the brown seaweed carotenoid fucoxanthin. Archives of Biochemistry and Biophysics, 686, 108364. https:// doi.org/10.1016/j.abb.2020.108364

Miyashita, K., Nishikawa, S., Beppu, F., Tsukui, T., Abe, M. and Hosokawa, M. (2011). The allenic carotenoid fucoxanthin, a novel marine nutraceutical from brown seaweeds. Journal of the Science of Food and Agriculture, 91(7), 1166-1174. https:// doi.org/10.1002/jsfa.4353

Mohibbullah, M., Haque, M.N., Khan, M.N.A., Park, I.S., Moon, I.S. and Hong, Y.K. (2018). Neuroprotective effects of fucoxanthin and its derivative fucoxanthinol from the phaeophyte Undaria pinnatifida attenuate oxidative stress in hippocampal neurons. Journal of Applied Phycology, 30(6), 3243-3252. https://doi.org/10.1007/s10811018-1458-6

Montaser, R. and Luesch, H. (2011). Marine natural products: A new wave of drugs? Future Medicinal Chemistry, 3(12), 1475-1489. https:// doi.org/10.4155/fmc. 11.118

Peng, J., Yuan, J.P., Wu, C.F. and Wang, J.H. (2011). Fucoxanthin, a marine carotenoid present in brown seaweeds and diatoms: Metabolism and bioactivities relevant to human health. Marine Drugs, 9(10), 1806 -1828. https://doi.org/10.3390/md9101806

Rao, A.R., Sarada, R. and Ravishankar, G.A. (2007). Stabilization of astaxanthin in edible oils and its use as an antioxidant. Journal of the Science of Food and Agriculture, 87(6), 957-965. https://doi.org/10.1002/ jsfa. 2766

Rao, Q., Rocca-Smith, J. R. and Labuza, T. P. (2012). Moisture-induced quality changes of hen egg white proteins in a protein/water model system. Journal of Agricultural and Food Chemistry, 60(42), 1062510633. https://doi.org/10.1021/jf302402k

Roiaini, M., Seyed, H. M., Jinap, S. and Norhayati, H. (2016). Effect of extraction methods on yield, oxidative value, phytosterols and antioxidant content of cocoa butter. International Food Research Journal, 23(1), 47-54.

Shang, Y. F., Kim, S.M., Lee, W.J. and Um, B.H. (2011). Pressurized liquid method for fucoxanthin extraction from Eisenia bicyclis (Kjellman) Setchell. Journal of Bioscience and Bioengineering, 111(2), 237-241.

https://doi.org/10.1016/ j.jbiosc. 2010.10 .008

Shannon, E. and Abu-Ghannam, N. (2017). Optimisation of fucoxanthin extraction from Irish seaweeds by response surface methodology. Journal of Applied Phycology, 29(2), 1027-1036. https:// doi.org/10.1007/s10811-016-0983-4

Torres-Moreno, M., Torrescasana, E., Salas-Salvadó, J. and Blanch, C. (2015). Nutritional composition and fatty acids profile in cocoa beans and chocolates with different geographical origin and processing conditions. Food Chemistry, 166, 125-132. https:// doi.org/10.1016/j.foodchem.2014.05.141

Udayasoorian, L., Peter, M., Sabina, K., Indumathi, C. and Muthusamy, S. (2017). Comparative evaluation on shelf life extension of MAP packed Litopenaeus vannamei shrimp treated with natural extracts. $L W T$ Food Science and Technology, 77, 217-224. https:// doi.org/10.1016/j.lwt.2016.11.046 
Vera Zambrano, M., Dutta, B., Mercer, D.G., MacLean, H.L. and Touchie, M.F. (2019). Assessment of moisture content measurement methods of dried food products in small-scale operations in developing countries: A review. Trends in Food Science and Technology, 88, 484-496. https:// doi.org/10.1016/j.tifs.2019.04.006

Wells, M.L., Potin, P., Craigie, J.S., Raven, J.A., Merchant, S.S., Helliwell, K.E., Smith, A.G., Camire, M.E. and Brawley, S.H. (2017). Algae as nutritional and functional food sources: revisiting our understanding. Journal of Applied Phycology, 29 (2), 949-982. https://doi.org/10.1007/s10811-0160974-5

Xiao, X., Si, X., Yuan, Z., Xu, X. and Li, G. (2012). Isolation of fucoxanthin from edible brown algae by microwave-assisted extraction coupled with highspeed counter current chromatography. Journal of Separation Science, 35(17), 2313-2317. https:// doi.org/10.1002/jssc.201200231

Yu, R.X., Yu, R.T. and Liu, Z. (2018). Inhibition of two gastric cancer cell lines induced by fucoxanthin involves downregulation of Mcl-1 and STAT3. Human Cell, 31(1), 50-63. https://doi.org/10.1007/ s13577-017-0188-4

Zhao, D., Yu, D., Kim, M., Gu, M.Y., Kim, S.M., Pan, C.H., Kim, G.H. and Chung, D. (2019). Effects of temperature, light, and $\mathrm{pH}$ on the stability of fucoxanthin in an oil-in-water emulsion. Food Chemistry, 291, 87-93. https://doi.org/10.1016/ j.foodchem.2019.04.002 